\title{
Temperature and duration of heating of sunflower oil affect ruminal biohydrogenation of linoleic acid in vitro
}

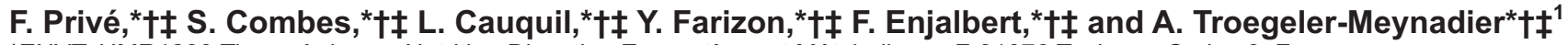 \\ ${ }^{*}$ ENVT, UMR1289 Tissus Animaux Nutrition Digestion Ecosystème et Métabolisme, F-31076 Toulouse Cedex 3, France \\ †INRA, UMR1289 Tissus Animaux Nutrition Digestion Ecosystème et Métabolisme, F-31326 Castanet-Tolosan, France \\ fUniversité de Toulouse, INPT ENSAT, UMR1289 Tissus Animaux Nutrition Digestion, F-31326 Castanet-Tolosan, France
}

\section{ABSTRACT}

Sunflower oil heated at 110 or $150^{\circ} \mathrm{C}$ for 1,3 , or $6 \mathrm{~h}$ was incubated with ruminal content in order to investigate the effects of temperature and duration of heating of oil on the ruminal biohydrogenation of linoleic acid in vitro. When increased, these 2 parameters acted together to decrease the disappearance of linoleic acid in the media by inhibiting the isomerization of linoleic acid, which led to a decrease in conjugated linoleic acids and trans-C18:1 production. Nevertheless, trans-10 isomer production increased with heating temperature, suggesting an activation of $\Delta^{9}$-isomerization, whereas trans-11 isomer production decreased, traducing an inhibition of $\Delta^{12}$-isomerization. The amount of peroxides generated during heating was correlated with the proportions of biohydrogenation intermediates so that they might explain, at least in part, the observed effects. The effects of heating temperature and duration on ruminal bacteria community was assessed using capillary electrophoresis single-strand conformation polymorphism. Ruminal bacterial population significantly differed according to heating temperature, but was not affected by heating duration. Heating of fat affected ruminal biohydrogenation, at least in part because of oxidative products generated during heating, by altering enzymatic reactions and bacterial population.

Key words: ruminal biohydrogenation, conjugated linoleic acid, heat processing, lipid peroxidation

\section{INTRODUCTION}

Conjugated linoleic acid (CLA) is a collective term for positional and geometrical isomers of linoleic acid (cis-9,cis-12-C18:2) with conjugated double bonds. Among them, cis-9,trans-11-CLA and trans-10,cis12-CLA have been reported to prevent some diseases like cancer, obesity, and arteriosclerosis (Pariza et al.,

Received July 1, 2009.

Accepted November 9, 2009.

${ }^{1}$ Corresponding author: a.troegeler@envt.fr
2001). In particular, cis-9,trans-11-CLA was shown to inhibit the cancer genesis in animal models. However, trans-10, cis-12-CLA was also reported to have potential adverse effects in humans in some cases, like insulin resistance in obese men with the metabolic syndrome (Riserus et al., 2002). Many foods contain CLA, with dairy products having the highest concentrations.

In dairy cows, milk CLA have 2 origins. The first origin is their formation during microbial ruminal biohydrogenation (BH) of cis-9, cis-12-C18:2, which begins with isomerization, mediated by several bacterial isomerases leading to several CLA isomers (Enjalbert and Troegeler-Meynadier, 2009), such as $\Delta^{12}$-isomerase and $\Delta^{9}$-isomerase that produce cis-9,trans-11-CLA and trans-10,cis-12-CLA, respectively (Griinari and Bauman, 1999). Thereafter, initial reduction produces different trans-octadecenoic acid (trans-C18:1) isomers: trans-11-C18:1 (also called vaccenic acid) and trans10-C18:1, respectively, for the above-mentioned CLA isomers. Finally, subsequent reduction produces stearic acid (C18:0). Because of its rapid reduction, very little CLA flows out of the rumen, implying that ruminal origin is of minor importance for milk CLA. A more significant origin of milk CLA is the mammary desaturation of trans-11-C18:1 into cis-9,trans-11-CLA (Griinari et al., 2000). Trans-11-C18:1 is an intermediate of ruminal BH of both cis-9,cis-12-C18:2 and $\alpha$-linolenic acid (cis9,cis-12,cis-15-C18:3). Thus, milk CLA content could be modulated by factors affecting cis-9,cis-12-C18:2 and cis-9,cis-12,cis $15-\mathrm{C} 18: 3 \mathrm{BH}$ as well as factors affecting desaturation in the mammary gland.

One way to efficiently increase CLA milk concentrations is the addition of a fat supplement to the dairy cow diet, particularly fat rich in cis-9,cis-12-C18:2 and cis-9, cis-12,cis-15-C18:3. In dairy cow diets, fat is usually sourced from oilseeds, which are often heated (e.g., by roasting or extrusion). Among studies, these processes have been shown to have variable effects on $\mathrm{BH}$ that need to be specified and explained. Heated oilseeds often induced a decrease of cis-9, cis-12-C18:2 and cis9,cis-12,cis-15-C18:3 BH in vivo (Gonthier et al., 2005), in situ (Chouinard et al., 1997b; Troegeler-Meynadier 
et al., 2006b) and in vitro (Reddy et al., 1994); however, this partial protection of PUFA against BH was not always noticed (Chouinard et al., 1997a; Akraim et al., 2006; Neves et al., 2007). Moreover, in most of these studies, heat treatments resulted in an accumulation of $\mathrm{BH}$ intermediates, particularly cis-9,trans-11-CLA, or trans-11-C18:1, or both.

Oilseeds heating effects on ruminal lipid digestion could be caused by a modification of the seed coat protection, a reduction of the amount of PUFA subjected to $\mathrm{BH}$, or the production of oxidation products (Reddy et al., 1994). These products could act on $\mathrm{BH}$ or on the biohydrogenating ruminal bacteria because anaerobes are known to be sensitive to peroxides (Brioukhanov and Netrusov, 2004). Oil heating can be an efficient model for the study of the effects of heat-induced lipid modifications on ruminal $\mathrm{BH}$.

The purpose of this study was to investigate the effects of 2 main modulators of the heating process, the duration of heating ( 1 vs. 3 vs. $6 \mathrm{~h}$ ) and the temperature of heating (110 vs. $\left.150^{\circ} \mathrm{C}\right)$, on cis-9, cis-12-C18:2 $\mathrm{BH}$ in ruminal cultures in vitro. The relationship between $\mathrm{BH}$ and the level of oil oxidation induced by heating (evaluated by peroxide value) was investigated, and the effects of heating on the structure of the bacterial community was studied using capillary electrophoresis single-strand conformation polymorphism (CE-SSCP).

\section{MATERIALS AND METHODS}

\section{In Vitro Cultures}

The oxidized oil was prepared by heating $20 \mathrm{~mL}$ of a commercial sunflower oil at 110 or $150^{\circ} \mathrm{C}$ for 1,3 , or 6 $\mathrm{h}$ in a crystallizing dish (9 $\mathrm{cm}$ in diameter). The heated oils were kept $1 \mathrm{~h}$ at ambient conditions to mimic cooling conditions after industrial heating processes, and then were frozen at $-80^{\circ} \mathrm{C}$ in 2 -mL syringes until use. In parallel, nonheated oil was frozen in syringes to be used as a control for both the efficiency of the $\mathrm{BH}$ in our in vitro incubation system and for the global effect of heating.

Ruminal incubations were performed in a water bath rotary shaker (Aquatron, Infors AG, Bottmingen, Germany). Ruminal fluid was obtained from a fistulated, nonlactating Holstein cow receiving an alfalfa hay-based diet $(5 \mathrm{~kg}$ of alfalfa hay, $2 \mathrm{~kg}$ of wheat straw, $2.5 \mathrm{~kg}$ of corn meal, and $0.3 \mathrm{~kg}$ of a minerals and vitamins supplement, as fed). The cow was allowed to adapt to this diet for $3 \mathrm{wk}$ before the beginning of the experiment. Rumen fluid was taken from the cow with a vacuum pump 30 min after feeding and strained through a metal sieve (1.6-mm mesh). Rumen fluid was transferred quickly to the laboratory in anaerobic conditions at $39^{\circ} \mathrm{C}$.
Eighty milliliters of strained ruminal fluid were incubated in a $250-\mathrm{mL}$ Erlenmeyer flask containing 200 $\mathrm{mg}$ of oil, $3 \mathrm{~g}$ of dehydrated alfalfa, and $80 \mathrm{~mL}$ of a bicarbonate buffer solution composed of $19.5 \mathrm{~g} / \mathrm{L}$ of $\mathrm{Na}_{2} \mathrm{HPO}_{4} \cdot 2 \mathrm{H}_{2} \mathrm{O}, 9.24 \mathrm{~g} / \mathrm{L}$ of $\mathrm{NaHCO}_{3}, 0.705 \mathrm{~g} / \mathrm{L}$ of $\mathrm{NaCl}, 0.675 \mathrm{~g} / \mathrm{L}$ of $\mathrm{KCl}, 0.108 \mathrm{~g} / \mathrm{L}$ of $\mathrm{CaCl}_{2} \cdot 2 \mathrm{H}_{2} \mathrm{O}$, and $0.180 \mathrm{~g} / \mathrm{L}$ of $\mathrm{MgSO}_{4} \cdot 7 \mathrm{H}_{2} \mathrm{O}$. The buffer solution was prewarmed to $39^{\circ} \mathrm{C}$ and saturated with $\mathrm{CO}_{2}$. The filled flasks were gassed with $\mathrm{CO}_{2}$ and placed in the water bath at $39^{\circ} \mathrm{C}$. Flasks were then closed with a rubber cap crossed by a plastic tube leading into the water to vent fermentation gas without allowing the entrance of oxygen. Flasks were stirred at $130 \mathrm{rpm}$ and kept safe from the light during the 6 -h incubation.

Two replicates of the control and of each heat treatment were incubated during each of the $3 \mathrm{~d}$ of culture (i.e., a total of 6 replicates per treatment). Each day, 2 blanks (without fat and not incubated) were prepared to analyze the initial state of media. At the end of the incubation, fermentations were stopped by placing the flasks into ice water, $\mathrm{pH}$ was measured, and $2 \times 200$ $\mu \mathrm{L}$ were sampled for bacterial community analysis. The contents of the flasks were then immediately frozen. Samples were freeze-dried (Virtis Freezemobile 25, Virtis, Gardiner, NY), weighed, ground and homogenized in a ball mill (Dangoumau, Prolabo, Nogent-sur-Marne, France), and kept at $-18^{\circ} \mathrm{C}$ for later analysis.

\section{Fatty Acids and Peroxides Analysis}

The degree of oxidation of oils was estimated by the peroxide value (PV; AFNOR, 2004), which was expressed as milliequivalents per kilogram $(\mathrm{mEq} / \mathrm{kg})$ of oil. The fatty acids of nonheated oils, heated oils, and incubated media were extracted and methylated in situ using the procedure of Park and Goins (1994), except that the solution of $14 \%$ of boron trifluoride in methanol was replaced by a solution of methanolacetylchloride (10:1). Nonadecanoic acid (C19:0) was used as the internal standard at a dose of $0.8 \mathrm{mg}$. The fatty acid methyl esters were then quantified by gas chromatography (Agilent 6890N, equipped with a model 7683 auto injector, Network GC System, Palo Alto, CA) using a fused silica capillary column $(100 \mathrm{~m} \times$ $0.25 \mathrm{~mm}$ i.d., $0.20-\mu \mathrm{m}$ film thickness; CPSil88,Varian, Middelburg, the Netherlands).

For analysis, the flame ionization detector temperature was maintained at $260^{\circ} \mathrm{C}$ and the injector at $255^{\circ} \mathrm{C}$; the split ratio was 1:50. Hydrogen was the carrier gas, with a constant flow of $1 \mathrm{~mL} / \mathrm{min}$. The samples were injected in $1 \mu \mathrm{L}$ of hexane. The initial temperature of the oven was $60^{\circ} \mathrm{C}$, which was held for $2 \mathrm{~min}$; it was then increased by $10^{\circ} \mathrm{C} / \mathrm{min}$ to $150^{\circ} \mathrm{C}$, held at $150^{\circ} \mathrm{C}$ for $12 \mathrm{~min}$, increased by $2^{\circ} \mathrm{C} / \mathrm{min}$ to $175^{\circ} \mathrm{C}$, held at 
$175^{\circ} \mathrm{C}$ for $20 \mathrm{~min}$, increased by $20^{\circ} \mathrm{C} / \mathrm{min}$ to a final temperature of $225^{\circ} \mathrm{C}$, and maintained at $225^{\circ} \mathrm{C}$ for 10 min. This temperature program allowed the separation of cis-15-C18:1 from C19:0, but did not allow the separation of cis-9,cis-12,cis-15-C18:3 from $\mathrm{C} 20: 1$ and did not correctly separate trans-C18:1 isomers. Therefore, a second temperature program was used to separate these coeluted fatty acids. For this analysis, the flameionization detector temperature was maintained at $260^{\circ} \mathrm{C}$ and the injector at $255^{\circ} \mathrm{C}$; the split ratio was 1:50. Hydrogen was the carrier gas, with a constant pressure of $160 \mathrm{kPa}$. The samples were injected in 0.5 $\mu \mathrm{L}$ of hexane. The initial temperature of oven was $60^{\circ} \mathrm{C}$, which was held for $3 \mathrm{~min}$; it was then increased by $8^{\circ} \mathrm{C} /$ min to $190^{\circ} \mathrm{C}$, held at $190^{\circ} \mathrm{C}$ for $13 \mathrm{~min}$, increased by $5^{\circ} \mathrm{C} / \mathrm{min}$ to $225^{\circ} \mathrm{C}$, held at $225^{\circ} \mathrm{C}$ for $10 \mathrm{~min}$, increased by $10^{\circ} \mathrm{C} / \mathrm{min}$ to a final temperature of $230^{\circ} \mathrm{C}$, and maintained for 10 min. Peaks were identified and quantified by comparison with commercial standards (Sigma Co., St. Louis, MO), except trans-C18:1 other than trans-9and trans-11C18:1, which were identified by order of elution. The fatty acid concentrations were expressed as milligrams per kilogram of DM.

\section{Bacterial Community Analysis}

Bacterial community analysis was performed as described by Michelland et al. (2009b). Briefly, total DNA was extracted and purified with QIAamp DNA Stool Mini kit (Qiagen Ltd., West Sussex, UK) directly from approximately $0.2 \mathrm{~g}$ of sample. The $\mathrm{V} 3$ region of the $16 \mathrm{~S}$ rRNA genes of bacterial species, corresponding to a 205-bp fragment in Escherichia coli, were used as a diversity marker by performing PCR using the primers W49 5'-ACGGTCCAGACTCCTACGGG-3' and 6FAM-labeled W34 5'-TTACCGCGGCGTGCTGGCAC-3' (Delbès et al., 1998; Zumstein et al., 2000). Then, $\mathrm{PCR}$ was carried out in $50-\mu \mathrm{L}$ reaction mixtures containing $5 \mu \mathrm{L}$ of $10 \times$ PCR buffer (PfuUltra II, Stratagene, La Jolla, CA), $0.2 \mu M$ of each primer, $200 \mu M$ of each dNTP, 0.25 U of Pfu Ultra II Fusion HS DNA polymerase (Stratagene), $25 \mu \mathrm{g}$ of BSA (Biolabs), and $1 \mu \mathrm{L}$ of $200 \times$ diluted DNA extract. The temperature program consisted of $2 \mathrm{~min}$ at $95^{\circ} \mathrm{C} ; 30$ cycles of $30 \mathrm{~s}$ at $94^{\circ} \mathrm{C}, 30 \mathrm{~s}$ at $61^{\circ} \mathrm{C}$, and $30 \mathrm{~s}$ at $72^{\circ} \mathrm{C}$; and a final extension of $3 \mathrm{~min}$ at $72^{\circ} \mathrm{C}$. The PCR products were checked for appropriate size by $1 \%$ agarose gel electrophoresis.

Samples were then analyzed by the method of CESSCP, a capillary electrophoretic method based on the heterogeneity of single-stranded ribotype secondary structure providing different mobility through a gel. An internal standard using a different fluorochrome 6-carboxy-X-rhodamine (Applied Biosystems, Foster
City, CA) was analyzed simultaneously. The SSCP mix contained $1 \mu \mathrm{L}$ of PCR product, $7.8 \mu \mathrm{L}$ of deionized formamid (Genescan, Applied Biosystems), and 0.2 $\mu \mathrm{L}$ of the internal standard fluorochrome 6-carboxy-Xrhodamine. The mix was denatured at $95^{\circ} \mathrm{C}$ for $5 \mathrm{~min}$ and placed on ice before loading. Then, CE-SSCP was performed on an ABI Prism 3100 Genetic Analyzer using a capillary $36 \mathrm{~cm}$ in length and a $7.2 \%$ nondenaturing polymer consisting of $80 \%$ CAP polymer (Applied Biosystems), $10 \%$ glycerol, and 10\% 10× Tris-borate EDTA buffer (Applied Biosystems). Electrophoresis was performed at $25^{\circ} \mathrm{C}$ for $3,500 \mathrm{~s}$ at $15 \mathrm{KV}$ and produced chromatograms containing both sample and internal standard signals. Bacterial communities were spread out in about 1,200 scans. The CE-SSCP data processing was computed with StatFingerprints software (Michelland et al., 2009a), and CE-SSCP profiles were aligned using pairwise alignment of their internal standard with the same reference internal standard. Simpson's diversity index $\left(\mathbf{D}^{\prime}\right)$ was calculated as follows (Rosenzweig, 1995):

$$
\mathrm{D}^{\prime}=-\log \Sigma a_{i}^{2}
$$

where $a_{i}$ corresponds to the area of the $i$ th peak.

\section{Calculations}

The rates and efficiencies of the cis-9,cis-12-C18:2 isomerization ( $\mathbf{v} \mathbf{1}$ and $\mathbf{E} 1$, respectively), CLA reduction (v2 and E2, respectively), and trans-C18:1 reduction (v3 and E3, respectively) were calculated as described previously by Troegeler-Meynadier et al. (2006a):

$$
\begin{gathered}
\mathrm{v} 1=([\mathrm{C} 18: 2] \mathrm{b}-[\mathrm{C} 18: 2] \mathrm{e}) / 6 \text { and } \\
\mathrm{E} 1=([\mathrm{C} 18: 2] \mathrm{b}-[\mathrm{C} 18: 2] \mathrm{e}) /[\mathrm{C} 18: 2] \mathrm{b},
\end{gathered}
$$

where 6 is the incubation time and $[\mathrm{C} 18: 2] \mathrm{b}$ and [C18:2] e represent the concentration of $\mathrm{C} 18: 2$ at the beginning and at the end of the 6 -h incubation, respectively.

$$
\begin{gathered}
\mathrm{v} 2=([\mathrm{C} 18: 2] \mathrm{b}-[\mathrm{C} 18: 2] \mathrm{e}+[\mathrm{CLA}] \mathrm{b}-[\mathrm{CLA}] \mathrm{e}) / 6 \text { and } \\
\mathrm{E} 2=([\mathrm{C} 18: 2] \mathrm{b}-[\mathrm{C} 18: 2] \mathrm{e}+[\mathrm{CLA}] \mathrm{b} \\
-[\mathrm{CLA}] \mathrm{e}) /([\mathrm{C} 18: 2] \mathrm{b}-[\mathrm{C} 18: 2] \mathrm{e}+[\mathrm{CLA}] \mathrm{b}),
\end{gathered}
$$

where [CLA $] \mathrm{b}$ and $[\mathrm{CLA}] \mathrm{e}$ represent the concentration of total CLA isomers measured at the beginning and at the end of the 6 -h incubation, respectively. 


$$
\begin{aligned}
& \mathrm{v} 3=([\mathrm{C} 18: 2] \mathrm{b}-[\mathrm{C} 18: 2] \mathrm{e}+[\mathrm{CLA}] \mathrm{b}-[\mathrm{CLA}] \mathrm{e} \\
& +[\text { trans-C18:1]b }-[\text { trans-C18:1]e)/6 and } \\
& \mathrm{E} 3=([\mathrm{C} 18: 2] \mathrm{b}-[\mathrm{C} 18: 2] \mathrm{e}+[\mathrm{CLA}] \mathrm{b}-[\mathrm{CLA}] \mathrm{e} \\
& +[\text { trans-C18:1]b }-[\text { trans-C18:1]e }) /([\mathrm{C} 18: 2] \mathrm{b}
\end{aligned}
$$

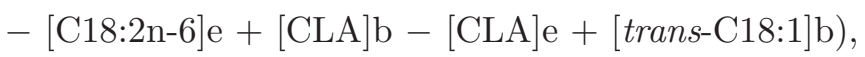

where [trans-C18:1]b and [trans-C18:1]e represent the concentration of total trans-C18:1 isomers measured at the beginning and at the end of the 6 -h incubation period, respectively.

For each fatty acid, production or disappearance was calculated as amount in incubated flask - (amount in blank + amount from added oil).

\section{Data Analysis}

Fatty acids production or disappearance, rates and efficiencies of $\mathrm{BH}$, and $\mathrm{D}^{\prime}$ of bacterial community were analyzed using the General Linear Model of SYSTAT (version 9, SPSS Inc., Chicago, IL) and were reported as mean values with standard errors of the mean.

Data were analyzed by ANOVA according to the model

$$
\begin{aligned}
\text { variable } & =\text { mean }+ \text { effect day of incubation } \\
& + \text { effect oil treatment }+\varepsilon,
\end{aligned}
$$

with 3 levels for the day of incubation and 7 levels for oil treatment (control or 110 or $150^{\circ} \mathrm{C}$ for 1,3 , or $6 \mathrm{~h}$ ), and $\varepsilon$ representing the residual error. When significant differences were found, means of heated oils were compared with the control by a pairwise Dunnett's comparison. The effects of temperature, duration of heating, and their interaction were analyzed on data obtained with heated oils; the effect of temperature was analyzed by 1-dimensional contrast, and the effects of duration of heating and temperature $\times$ duration interaction were analyzed by multidimensional contrasts.

Linear relationships were investigated between PV and fatty acids involved in cis-9,cis-12-C18:2 BH (cis9, cis-12-C18:2, cis-9,trans-11-CLA, trans-10,cis-12CLA, trans-11-C18:1, trans-10-C18:1, and C18:0) and between PV and kinetic parameters of BH (v1, E1, v2, E2, v3, and E3).

Linear relationships were then investigated between $\mathrm{D}^{\prime}$ and $\mathrm{PV}$ and between $\mathrm{D}^{\prime}$ and intermediates and kinetic parameters of cis-9,cis-12-C18:2 BH. For the latter regression, the intercept was not different from zero so that a zero-intercept regression was computed. Significance was declared at $P \leq 0.05$.

To compare the structure of the bacterial communities, the pairwise Euclidean distances of the 33 CE-SS$\mathrm{CP}$ profiles were used. To explore this distance matrix, nonmetric multidimensional scaling was performed using 10,000 random starts. Analysis of similarity (ANOSIM) was performed on the distance matrix using 10,000 Monte Carlo permutations. Global ANOSIM was performed to test the fixed effects of oil treatment (all data) and of heating temperature and duration (excluding $\mathrm{C}$ data). The ANOSIM R-value indicated the extent to which the groups differed and was between 0 (no separation) and 1 (well-separated groups).

\section{RESULTS}

\section{Effects of Duration and Temperature of Heating on Oil}

The PV of heated oils are presented in Table 1 with their respective amounts of oleic acid (cis-9-C18:1), cis9,cis-12-C18:2, and cis-9, cis-12,cis-15-C18:3. Peroxidation of oil increased with duration and temperature of heating. The oil heated at $150^{\circ} \mathrm{C}$ for $6 \mathrm{~h}$ (treatment 150-6) was characterized by a very high PV compared with the other heated oils. Initial amounts of unsaturated fatty acids weakly varied among treated oils.

\section{Effects of Duration and Temperature of Oil Heating on Fatty Acids Disappearance and Production After the 6-h Incubation with Ruminal Fluid}

Among short- and medium-chain fatty acids, the amounts of produced C7:0 and C8:0 increased with heating, and anteiso-C13:0 was not produced in the presence of heated oils (Table 2). Quantity and percentage of cis-9-C18:1 and cis-9,cis-12,cis-15-C18:3 disappearance were not affected by heat treatments. The amounts and percentages by which cis-9, cis-12-C18:2 disappeared were decreased by both the longest duration and $150^{\circ} \mathrm{C}$ heating, acting in synergy and leading to the lowest values for treatment 150-6. These conditions also decreased total CLA and trans-C18:1 production. The production of cis-11-C18:1 was increased by $150^{\circ} \mathrm{C}$ heating; the highest value was obtained for treatment $150-6$.

Among CLA isomers (Table 3), cis-9,trans-11-CLA production was significantly affected by heating: the 6-h duration and $150^{\circ} \mathrm{C}$ temperature acted in synergy to greatly decrease cis-9,trans-11-CLA production for treatment 150-6. The production of cis-9,cis-11-CLA 
Table 1. Peroxide values (PV; $\mathrm{mEq} / \mathrm{kg}$ of oil) and unsaturated fatty acids content ( $\mathrm{g} / 100 \mathrm{~g}$ of oil) of sunflower oils before and after heating at 110 or $150^{\circ} \mathrm{C}$ for 1,3 , or $6 \mathrm{~h}$

\begin{tabular}{|c|c|c|c|c|c|c|c|}
\hline \multirow[b]{2}{*}{ Item } & \multirow[b]{2}{*}{ No heating } & \multicolumn{3}{|c|}{$110^{\circ} \mathrm{C}$} & \multicolumn{3}{|c|}{$150^{\circ} \mathrm{C}$} \\
\hline & & $1 \mathrm{~h}$ & $3 \mathrm{~h}$ & $6 \mathrm{~h}$ & $1 \mathrm{~h}$ & $3 \mathrm{~h}$ & $6 \mathrm{~h}$ \\
\hline $\mathrm{PV}^{1}$ & $4.8^{\mathrm{e}}$ & $11.1^{\mathrm{de}}$ & $31.4^{\mathrm{cd}}$ & $63.5^{\mathrm{b}}$ & $27.7^{\mathrm{d}}$ & $54.5^{\mathrm{bc}}$ & $237.8^{\mathrm{a}}$ \\
\hline cis-9-C18: $1^{2}$ & 23.3 & 24.0 & 23.8 & 23.7 & 22.3 & 24.0 & 22.9 \\
\hline cis- 9, cis- $12-\mathrm{C} 18: 2^{2}$ & 47.7 & 49.4 & 48.8 & 48.1 & 45.7 & 48.8 & 44.1 \\
\hline cis-9,cis-12,cis-15-C18:3 ${ }^{2}$ & 0.2 & 0.2 & 0.2 & 0.2 & 0.2 & 0.2 & 0.2 \\
\hline
\end{tabular}

${ }^{\mathrm{a}-\mathrm{e}}$ Means within a row with different superscripts significantly differ $(P<0.05)$.

${ }^{1} \mathrm{SEM}$ of $\mathrm{PV}=2.1$ ( $\mathrm{n}=21,3$ repetitions per treatment $)$.

${ }^{2}$ Single determination.

was slightly affected by heating duration only, and the production of trans-9,trans-11-CLA was faintly decreased by $150^{\circ} \mathrm{C}$ heating. Conversely, trans-10, cis-12CLA production was significantly increased at $150^{\circ} \mathrm{C}$ heating, and a synergy between the 6-h duration and $150^{\circ} \mathrm{C}$ heating also existed, leading to the highest value for treatment 150-6.

Among trans-C18:1 isomers, an increase in the amount of trans-12-C18:1 produced was observed with $150^{\circ} \mathrm{C}$ temperature and the $3-\mathrm{h}$ and 6 -h durations of oil heating, leading to the maximum production for those treatments. Such an increase was also noticed for trans9-C18:1, but no interaction was observed between the 2 factors. The production of trans-10-C18:1 was increased by $150^{\circ} \mathrm{C}$ heating but was not affected by duration. The production of trans-11-C18:1 was strongly decreased in a synergistic manner by $150^{\circ} \mathrm{C}$ temperature and the 6-h duration of heating of oil, leading to the lowest value for 150-6. The production of trans-16-C18:1 was affected only by $150^{\circ} \mathrm{C}$ heating; no production of trans16-C18:1 was observed in the media containing the oils heated at $150^{\circ} \mathrm{C}$.

An increase in heating temperature led to a significant increase in production of trans-10 isomers, whereas the amount of trans-11 isomers produced decreased significantly for the 6 -h heating duration and $150^{\circ} \mathrm{C}$ heating. As a result, trans-10 production was the highest and trans-11 production the lowest for 150-6 (Table 3).

\section{Effects of Temperature and Duration of Oil Heating on Linoleic Acid Biohydrogenation Kinetic Parameters After the 6-h Incubation with Ruminal Fluid}

Increase in duration and temperature of heating significantly decreased v1 and E1 (isomerization), and heating temperature and duration acted in a synergic manner, leading to the lowest values for treatment 150-6 (Table 4). The rate of the first reduction, v2, decreased for the 6 -h duration and $150^{\circ} \mathrm{C}$ heating, the lowest value also being for treatment $150-6$, and the rate of the second reduction, v3, was weakly affected by heating. The efficiencies of both reductions (E2 and E3) were significantly increased by the 6-h heating duration, but only E2 was affected by temperature.

\section{Effects of Duration and Temperature of Oil Heating on Ruminal Bacterial Community After 6 h of In Vitro Incubation}

Duration of heating did not influence bacterial community structure (Table 5; $P=0.86$; ANOSIM R-value $=0)$, but bacterial community structure was affected by heating temperature $(P=0.01$; ANOSIM R-value $=0.21)$. Accordingly, the 2-dimensional nonmetric multidimensional scaling plot of the 33 CE-SSCP profiles from the ruminal cultures showed that bacterial communities could be separated according to heating temperature $\left(110\right.$ vs. $\left.150^{\circ} \mathrm{C}\right)$ (Figure 1$)$.

No effect of duration $(P=0.27)$ and temperature $(P=0.93)$ of heating was observed on bacterial community $\mathrm{D}^{\prime}$. However, this $\mathrm{D}^{\prime}$ was strongly and linearly related to all $\mathrm{BH}$ intermediates and kinetic parameters of cis-9,cis-12-C18:2 BH (Table 5).

\section{Relationships Between Intermediates and Kinetic Parameters of Linoleic Acid Biohydrogenation, Bacterial Community Diversity, and PV}

Among the fatty acids involved in cis-9,cis-12-C18:2 $\mathrm{BH}$, only C18:0 was not linked to PV (Table 6). The amount of cis-9,cis-12-C18:2 that disappeared from the media decreased when PV increased. The production of trans-10 isomers increased slowly but significantly with the increase of PV values, whereas trans-11 isomers were negatively, significantly, and more strongly linked with PV.

Among kinetic parameters of cis-9,cis-12-C18:2 BH, v1 and E1 (isomerization) were negatively linked with $\mathrm{PV}$, and the efficiencies of both reductions (E2 and 
Table 2. Effects of duration and temperature of heating of sunflower oil on production (positive values) or disappearance (negative values) of fatty acids (mg), and percentages of disappearance of oleic, linoleic, and linolenic acids after the 6 -h incubation with ruminal fluid

\begin{tabular}{|c|c|c|c|c|c|c|c|c|c|c|c|}
\hline \multirow[b]{2}{*}{ Item } & \multirow[b]{2}{*}{ No heating } & \multicolumn{3}{|c|}{$110^{\circ} \mathrm{C}$} & \multicolumn{3}{|c|}{$150^{\circ} \mathrm{C}$} & \multirow[b]{2}{*}{ SEM } & \multicolumn{3}{|c|}{$P$-value } \\
\hline & & $1 \mathrm{~h}$ & $3 \mathrm{~h}$ & $6 \mathrm{~h}$ & $1 \mathrm{~h}$ & $3 \mathrm{~h}$ & $6 \mathrm{~h}$ & & Duration & Temperature & $\begin{array}{l}\text { Duration } \times \\
\text { temperature }\end{array}$ \\
\hline \multicolumn{12}{|l|}{ Fatty acid balance (mg) } \\
\hline C6:0 & 0.87 & 1.04 & 1.38 & $1.73^{*}$ & $1.53^{*}$ & $1.70^{*}$ & $1.53^{*}$ & 0.061 & 0.10 & 0.15 & 0.11 \\
\hline C7:0 & 0.06 & 0.08 & 0.11 & $0.15^{*}$ & 0.12 & $0.13^{*}$ & $0.14^{*}$ & 0.006 & 0.03 & 0.32 & 0.42 \\
\hline C8:0 & 0.02 & 0.01 & 0.02 & 0.04 & 0.02 & 0.03 & $0.10^{*}$ & 0.003 & $<0.01$ & $<0.01$ & $<0.01$ \\
\hline C9:0 & 0.03 & 0.04 & 0.04 & 0.05 & 0.04 & 0.04 & 0.06 & 0.003 & 0.08 & 1.00 & 0.81 \\
\hline $\mathrm{C} 10: 0$ & 0.03 & 0.01 & 0.01 & 0.02 & 0.02 & 0.02 & 0.02 & 0.002 & 0.80 & 0.46 & 0.96 \\
\hline C11:0 & -0.33 & $-0.68^{*}$ & -0.66 & -0.58 & -0.65 & $-0.76^{*}$ & $-0.78^{*}$ & 0.034 & 0.92 & 0.21 & 0.47 \\
\hline $\mathrm{C} 12: 0$ & -0.01 & 0.00 & -0.09 & -0.03 & -0.10 & -0.17 & -0.13 & 0.033 & 0.62 & 0.22 & 0.99 \\
\hline C13:0 & 0.05 & 0.00 & 0.03 & 0.05 & 0.03 & 0.04 & 0.02 & 0.005 & 0.36 & 0.81 & 0.09 \\
\hline anteiso-C13:0 & 0.27 & $-0.01^{*}$ & $0.02^{*}$ & $0.00^{*}$ & $-0.01^{*}$ & $-0.07^{*}$ & $-0.08^{*}$ & 0.011 & 0.58 & 0.02 & 0.29 \\
\hline iso-C13:0 & 0.03 & -0.01 & 0.00 & 0.02 & 0.07 & -0.01 & 0.02 & 0.006 & 0.03 & 0.02 & $<0.01$ \\
\hline $\mathrm{C} 14: 0$ & 0.57 & -0.03 & 0.36 & 0.53 & 0.29 & 0.26 & 0.24 & 0.060 & 0.33 & 0.90 & 0.15 \\
\hline C15:0 & 0.65 & $0.36^{*}$ & 0.45 & 0.53 & 0.51 & $0.40^{*}$ & $0.37^{*}$ & 0.025 & 0.90 & 0.77 & 0.07 \\
\hline anteiso-C15:0 & 0.69 & $0.42^{*}$ & 0.55 & 0.61 & 0.64 & 0.57 & 0.52 & 0.021 & 0.85 & 0.24 & 0.02 \\
\hline iso-C15:0 & 0.32 & $0.16^{*}$ & 0.22 & 0.29 & 0.29 & $0.18^{*}$ & 0.20 & 0.013 & 0.48 & 0.89 & $<0.01$ \\
\hline C16:0 & -0.48 & -2.85 & -1.33 & 2.17 & 0.56 & -0.31 & -0.70 & 0.326 & 0.09 & 0.44 & 0.01 \\
\hline C16:1 & -0.18 & -0.17 & -0.14 & -0.12 & -0.13 & -0.38 & -0.12 & 0.039 & 0.35 & 0.46 & 0.31 \\
\hline C17:0 & 0.33 & 0.23 & 0.26 & 0.37 & 0.30 & 0.13 & 0.22 & 0.024 & 0.25 & 0.18 & 0.14 \\
\hline anteiso-C17:0 & 0.15 & 0.12 & 0.12 & 0.16 & 0.16 & 0.13 & 0.13 & 0.007 & 0.48 & 0.54 & 0.11 \\
\hline iso-C17:0 & 0.12 & 0.08 & 0.08 & 0.11 & 0.10 & 0.07 & 0.07 & 0.005 & 0.51 & 0.66 & 0.09 \\
\hline cis-10-C17:1 & 0.03 & 0.03 & 0.04 & 0.04 & 0.05 & 0.05 & 0.03 & 0.003 & 0.79 & 0.58 & 0.09 \\
\hline C18:0 & 27.90 & 29.80 & 30.82 & 31.76 & 35.75 & 31.77 & 31.46 & 0.796 & 0.90 & 0.29 & 0.46 \\
\hline anteiso-C18:0 & 0.08 & 0.08 & 0.10 & 0.01 & 0.12 & 0.11 & 0.09 & 0.011 & 0.18 & 0.09 & 0.47 \\
\hline iso-C18:0 & 0.03 & 0.01 & 0.00 & -0.01 & -0.01 & 0.01 & $-0.03^{*}$ & 0.005 & 0.11 & 0.25 & 0.68 \\
\hline cis-9-C18:1 & -15.17 & -14.91 & -15.17 & -14.15 & -13.16 & -15.55 & -14.20 & 0.253 & 0.05 & 0.23 & 0.0 \\
\hline cis-11-C18:1 & 0.84 & 0.87 & 0.84 & 0.70 & 0.93 & 1.08 & $1.35^{*}$ & 0.037 & 0.43 & $<0.01$ & 0.01 \\
\hline cis-15-C18:1 & 0.03 & 0.02 & 0.02 & 0.00 & 0.04 & 0.03 & 0.03 & 0.004 & 0.40 & 0.02 & 0.31 \\
\hline Total trans-C18:1 & 21.33 & 21.41 & 21.28 & 20.55 & 23.51 & 21.32 & $12.55^{*}$ & 0.342 & $<0.01$ & $<0.01$ & $<0.01$ \\
\hline cis-9,cis-12-C18:2 & -53.08 & -53.92 & -52.36 & -48.92 & -49.69 & -53.14 & $-41.43^{*}$ & 0.449 & $<0.01$ & $<0.01$ & $<0.01$ \\
\hline Total CLA ${ }^{1}$ & 5.36 & 6.13 & 4.81 & 4.13 & 4.96 & 4.58 & $1.09^{*}$ & 0.154 & $<0.01$ & $<0.01$ & 0.02 \\
\hline cis-9,cis-12,cis-15-C18:3 & -4.37 & -4.59 & -4.31 & -3.59 & -4.30 & -3.83 & -4.19 & 0.119 & 0.36 & 0.66 & 0.15 \\
\hline \multicolumn{12}{|l|}{ Disappearance (\%) } \\
\hline cis-9-C18:1 & 30.17 & 28.90 & 29.54 & 27.78 & 27.16 & 30.21 & 28.80 & 0.499 & 0.18 & 0.68 & 0.26 \\
\hline cis-9,cis-12-C18:2 & 50.13 & 49.52 & 48.54 & 46.10 & 48.69 & 49.39 & $42.10^{*}$ & 0.421 & $<0.01$ & 0.05 & 0.09 \\
\hline cis-9,cis-12,cis-15-C18:3 & 45.52 & 47.50 & 45.00 & 38.23 & 43.56 & 40.89 & 44.28 & 1.122 & 0.39 & 0.77 & 0.16 \\
\hline
\end{tabular}

${ }^{1} \mathrm{CLA}=$ conjugated linoleic acid.

*Treatment significantly $(P<0.05)$ differs from no heating (Dunnett's test). 
Table 3. Effects of duration and temperature of heating of sunflower oil on produced amounts (mg) of trans-C18:1 and CLA ${ }^{1}$ isomers after the 6-h incubation with ruminal fluid

\begin{tabular}{|c|c|c|c|c|c|c|c|c|c|c|c|}
\hline \multirow[b]{2}{*}{ Item } & \multirow[b]{2}{*}{ No heating } & \multicolumn{3}{|c|}{$110^{\circ} \mathrm{C}$} & \multicolumn{3}{|c|}{$150^{\circ} \mathrm{C}$} & \multirow[b]{2}{*}{ SEM } & \multicolumn{3}{|c|}{$P$-value } \\
\hline & & $1 \mathrm{~h}$ & $3 \mathrm{~h}$ & $6 \mathrm{~h}$ & $1 \mathrm{~h}$ & $3 \mathrm{~h}$ & $6 \mathrm{~h}$ & & Duration & Temperature & $\begin{array}{l}\text { Duration } \times \\
\text { temperature }\end{array}$ \\
\hline \multicolumn{12}{|l|}{ trans-C18:1 isomer } \\
\hline trans-4-C18:1 & 0.15 & 0.14 & 0.11 & 0.08 & 0.15 & 0.09 & 0.09 & 0.009 & 0.06 & 0.89 & 0.76 \\
\hline trans-5-C18:1 & 0.11 & 0.11 & 0.10 & 0.08 & 0.12 & 0.11 & 0.09 & 0.006 & 0.22 & 0.63 & 0.99 \\
\hline trans-6,7,8-C18:1 & 0.89 & 0.85 & 0.80 & 0.86 & 1.01 & 0.94 & 0.71 & 0.021 & 0.06 & 0.34 & 0.02 \\
\hline trans-9-C18:1 & 0.40 & 0.23 & 0.27 & 0.67 & 0.73 & 0.79 & $1.09^{*}$ & 0.050 & $<0.01$ & $<0.01$ & 0.91 \\
\hline trans-10-C18:1 & 0.79 & 0.68 & 0.79 & 0.79 & 1.01 & 1.08 & 1.15 & 0.040 & 0.47 & $<0.01$ & 0.96 \\
\hline trans-11-C18:1 & 16.51 & 16.72 & 16.47 & 15.20 & 18.36 & 15.77 & $7.25^{*}$ & 0.229 & $<0.01$ & $<0.01$ & $<0.01$ \\
\hline trans-12-C18:1 & 0.77 & 0.82 & 0.73 & 0.84 & 0.85 & $1.12^{*}$ & $1.10^{*}$ & 0.020 & 0.04 & $<0.01$ & $<0.01$ \\
\hline trans-13,14-C18:1 & 0.90 & 1.25 & 1.26 & 1.13 & 1.40 & 1.46 & 1.10 & 0.080 & 0.48 & 0.57 & 0.85 \\
\hline trans-15-C18:1 & 0.27 & 0.27 & 0.24 & 0.57 & 0.37 & 0.41 & 0.43 & 0.031 & 0.06 & 0.49 & 0.16 \\
\hline trans-16-C18:1 & 0.54 & 0.33 & 0.52 & 0.33 & $-0.50^{*}$ & $-0.46^{*}$ & $-0.46^{*}$ & 0.043 & 0.55 & $<0.01$ & 0.67 \\
\hline \multicolumn{12}{|l|}{ CLA isomer } \\
\hline trans-10,cis-12-CLA & 0.14 & 0.16 & 0.12 & 0.12 & 0.14 & 0.15 & $0.19^{*}$ & 0.004 & 0.15 & $<0.01$ & $<0.01$ \\
\hline cis-9,trans-11-CLA & 4.11 & 4.77 & 3.78 & 3.29 & 4.18 & 3.65 & $1.05^{*}$ & 0.101 & $<0.01$ & $<0.01$ & $<0.01$ \\
\hline cis-9,cis-11-CLA & 0.15 & 0.16 & 0.10 & 0.11 & 0.15 & 0.11 & $0.04^{*}$ & 0.009 & $<0.01$ & 0.22 & 0.15 \\
\hline trans-9,trans-11-CLA & 0.96 & 1.03 & 0.81 & 0.61 & 0.57 & 0.66 & 0.31 & 0.069 & 0.17 & 0.04 & 0.66 \\
\hline \multicolumn{12}{|l|}{ Sum } \\
\hline trans-10 isomers & 0.93 & 0.84 & 0.91 & 0.91 & 1.15 & 1.23 & $1.34^{*}$ & 0.041 & 0.46 & $<0.01$ & 0.78 \\
\hline trans-11 isomers & 21.58 & 22.53 & 21.06 & 19.11 & 23.12 & 20.09 & $8.61^{*}$ & 0.325 & $<0.01$ & $<0.01$ & $<0.01$ \\
\hline
\end{tabular}

$\stackrel{\complement}{{ }_{5}} \mathrm{CLA}=$ conjugated linoleic acid.

㐘 *Treatment significantly $(P<0.05)$ differs from no heating (Dunnett's test). 
Table 4. Effects of duration and temperature of heating of sunflower oil on rates (mg/L per hour) and efficiencies (\%) of the 3 reactions of linoleic acid biohydrogenation ${ }^{1}$ in the 6 -h incubation with ruminal fluid

\begin{tabular}{|c|c|c|c|c|c|c|c|c|c|c|c|}
\hline \multirow[b]{2}{*}{ Item } & \multirow[b]{2}{*}{ No heating } & \multicolumn{3}{|c|}{$110^{\circ} \mathrm{C}$} & \multicolumn{3}{|c|}{$150^{\circ} \mathrm{C}$} & \multirow[b]{2}{*}{ SEM } & \multicolumn{3}{|c|}{$P$-value } \\
\hline & & $1 \mathrm{~h}$ & $3 \mathrm{~h}$ & $6 \mathrm{~h}$ & $1 \mathrm{~h}$ & $3 \mathrm{~h}$ & $6 \mathrm{~h}$ & & Duration & Temperature & $\begin{array}{l}\text { Duration } \times \\
\text { temperature }\end{array}$ \\
\hline v1 & 55.29 & 56.16 & 54.54 & 50.96 & 51.76 & 55.35 & $43.15^{*}$ & 0.468 & $<0.01$ & $<0.01$ & $<0.01$ \\
\hline E1 & 50.13 & 49.52 & 48.54 & 46.10 & 48.69 & 49.39 & $42.10^{*}$ & 0.421 & $<0.01$ & 0.05 & 0.09 \\
\hline v2 & 49.71 & 49.78 & 49.53 & 46.66 & 46.51 & 50.58 & $41.49^{*}$ & 0.511 & $<0.01$ & $<0.01$ & 0.04 \\
\hline E2 & 88.38 & 87.81 & 89.56 & 90.54 & 88.73 & 90.42 & $94.97^{*}$ & 0.317 & $<0.01$ & $<0.01$ & 0.05 \\
\hline
\end{tabular}

${ }^{1} \mathrm{v} 1$ and $\mathrm{E} 1$ refer to the isomerization of cis-9,cis-12-C18:2 to conjugated linoleic acid (CLA); v2 and E2 refer to the reduction of CLA to transC18:1; v3 and E3 refer to the reduction of trans-C18:1 to C18:0.

*Treatment significantly $(P<0.05)$ differs from no heating (Dunnett's test).

E3) were positively linked with PV. However, although significant, $\mathrm{r}^{2}$ values were less than 0.7 . Diversity index was not linked to the peroxide content of the media.

\section{DISCUSSION}

\section{Effect of Heating on PV of Oils}

As expected, PV of oil increased with duration and temperature of heating, with the highest values for $150^{\circ} \mathrm{C}$ during the 6 -h incubation. For treatment $150-6$, the values obtained were very high compared with all other combinations of temperatures and durations of heating. The reaction of oxidation probably reached its propagation phase, characterized by an exponential increase of peroxides in the fat.

\section{Heating of Oil Affected Linoleic Acid Biohydrogenation}

Increasing duration and temperature of heating of sunflower oil, rich in cis-9, cis-12-C18:2, strongly affected cis-9,cis-12-C18:2 BH. The disappearance of cis-9,cis12-C18:2 was inhibited, leading to a decreased production of CLA and trans-C18:1, whereas disappearances of cis-9-C18:1 and cis-9,cis-12,cis-15-C18:3 remained unchanged. This inhibition of cis-9,cis-12-C18:2 disappearance could, at least partly, explain the protective effect of heat treatment of oilseeds against $\mathrm{BH}$ that was observed in some studies (Reddy et al., 1994; Chouinard et al., 1997b; Troegeler-Meynadier et al., 2006b). In these studies, the conditions of extrusion and roasting were often not specified apart from the temperature of heating. In studies where extrusion did not lead to a protection of PUFA against $\mathrm{BH}$, the temperature of extrusion was low, about $120^{\circ} \mathrm{C}$ (Akraim et al., 2006; Neves et al., 2007) as opposed to 140 to $160^{\circ} \mathrm{C}$ in studies where a protection was noticed. Duration of extrusion was probably not the same among studies because only 2 studies specified this: $30 \mathrm{~s}$ in the study of Neves et al.
(2007), who did not observe PUFA protection, and $43 \mathrm{~s}$ for Gonthier et al. (2005), who observed PUFA protection. For roasting, duration of heating is longer than for extrusion, which could explain that a protection of PUFA against $\mathrm{BH}$ was frequently observed (Reddy et al., 1994; Chouinard et al., 1997a; Troegeler-Meynadier et al., 2006b). The capacity to withstand BH that was observed when using heated oilseeds compared with raw oilseeds could be explained, at least in part, by the effect of duration and temperature of heating on the modulation of isomerization and subsequent disappearance of PUFA.

\section{Heating of Oil Affected CLA and Trans-C18:1 Production}

Contrary to the studies where heating of oilseeds resulted in an accumulation of $\mathrm{BH}$ intermediates (Chouinard et al., 1997a; Gonthier et al., 2005; Neves et

Table 5. Regression equations between bacterial population diversity index $\left(\mathrm{D}^{\prime}\right)$ of incubated ruminal fluid and disappeared or produced amounts $(\mathrm{mg})$ of fatty acids intermediates, rates $(\mathrm{mg} / \mathrm{L}$ per hour), and efficiencies (\%) of the 3 reactions of linoleic acid biohydrogenation, ${ }^{1}$ combining results obtained with heated and unheated oils $(n=42)$

\begin{tabular}{|c|c|c|}
\hline Regression equation & $\mathrm{r}^{2}$ & $P$-value \\
\hline cis-9,cis-12-C18:2 = -7.79 D' & 0.97 & $<0.01$ \\
\hline trans-10,cis-12-CLA $=0.02 \mathrm{D}^{\prime}$ & 0.96 & $<0.01$ \\
\hline cis-9,trans-11-CLA $=0.52 \mathrm{D}^{\prime}$ & 0.90 & $<0.01$ \\
\hline trans-10-C18:1 = $0.13 \mathrm{D}^{\prime}$ & 0.93 & $<0.01$ \\
\hline trans-11-C18:1 = $2.31 \mathrm{D}^{\prime}$ & 0.94 & $<0.01$ \\
\hline $\mathrm{C} 18: 0=4.88 \mathrm{D}^{\prime}$ & 0.97 & $<0.01$ \\
\hline $\mathrm{v} 1=8.12 \mathrm{D}^{\prime}$ & 0.97 & $<0.01$ \\
\hline $\mathrm{E} 1=7.35 \mathrm{D}^{\prime}$ & 0.97 & $<0.01$ \\
\hline $\mathrm{v} 2=7.42 \mathrm{D}^{\prime}$ & 0.97 & $<0.01$ \\
\hline $\mathrm{E} 2=13.89 \mathrm{D}^{\prime}$ & 0.98 & $<0.01$ \\
\hline $\mathrm{v} 3=4.23 \mathrm{D}^{\prime}$ & 0.98 & $<0.01$ \\
\hline $\mathrm{E} 3=7.39 \mathrm{D}^{\prime}$ & 0.98 & $<0.01$ \\
\hline
\end{tabular}

${ }^{1} \mathrm{v} 1$ and E1 refer to the isomerization of cis-9, cis-12-C18:2 to conjugated linoleic acid (CLA); v2 and E2 refer to the reduction of CLA to trans-C18:1; v3 and E3 refer to the reduction of trans-C18:1 to C18:0. 
Table 6. Regression equations between peroxide values (PV; $\mathrm{mEq} /$ $\mathrm{kg}$ of oil) and disappeared or produced amounts $(\mathrm{mg})$ of fatty acids intermediates, rates (v; mg/L per hour) and efficiencies (E; \%) of the 3 reactions of linoleic acid biohydrogenation, ${ }^{1}$ and bacterial population diversity index $\left(\mathrm{D}^{\prime}\right)$ of incubated ruminal fluid, combining results obtained with heated and unheated oils $(\mathrm{n}=42)$

\begin{tabular}{lcr}
\hline Regression equation & $\mathrm{r}^{2}$ & $P$-value \\
\hline cis-9, cis-12-C18:2 $=0.05 \mathrm{PV}-53.35$ & 0.41 & 0.01 \\
trans-10,cis-12-CLA $=0.0002 \mathrm{PV}+0.13$ & 0.54 & $<0.01$ \\
cis- 9, trans-11-CLA $=-0.01 \mathrm{PV}+4.41$ & 0.82 & $<0.01$ \\
trans-10-C18:1 $=0.002 \mathrm{PV}+0.80$ & 0.40 & $<0.01$ \\
trans-11-C18:1 = -0.04 PV + 17.76 & 0.83 & $<0.01$ \\
$\mathrm{C} 18: 0=0.01 \mathrm{PV}+30.85$ & 0.07 & 0.66 \\
$\mathrm{v} 1=-0.05 \mathrm{PV}+55.57$ & 0.41 & 0.01 \\
$\mathrm{E} 1=-0.03 \mathrm{PV}+49.65$ & 0.32 & 0.04 \\
$\mathrm{v} 2=-0.03 \mathrm{PV}+49.78$ & 0.28 & 0.08 \\
$\mathrm{E} 2=0.03 \mathrm{PV}+88.31$ & 0.69 & $<0.01$ \\
$\mathrm{v} 3=0.00 \mathrm{PV}+26.09$ & 0.10 & 0.52 \\
$\mathrm{E} 3=0.05 \mathrm{PV}+44.06$ & 0.60 & $<0.01$ \\
$\mathrm{D}^{\prime}=0.00 \mathrm{PV}+5.95$ & 0.23 & 0.20 \\
\hline
\end{tabular}

${ }^{1} \mathrm{v} 1$ and $\mathrm{E} 1$ refer to the isomerization of cis-9,cis-12-C18:2 to conjugated linoleic acid (CLA); v2 and E2 refer to the reduction of CLA to trans-C18:1; v3 and E3 refer to the reduction of trans-C18:1 to C18:0.

al., 2007), in this study, the heating of oil for $6 \mathrm{~h}$ at $150^{\circ} \mathrm{C}$ induced a significant diminution of total CLA and trans-C18:1 production. In the study of TroegelerMeynadier et al. (2006b), the increase of CLA and trans-C18:1 production with extruded compared with raw soybeans was associated with a decrease in the efficiencies of both reductions. Conversely, in the present study, heat treatment of oil increased the efficiencies of both reductions, which means that reduction was not inhibited. Therefore, the low production of CLA and trans-C18:1 observed with heated oils could be caused only by the inhibition of isomerization. Indeed, the inhibition of the isomerization led to a lack of substrate for the subsequent reaction, the reduction of CLA, and so to a decrease in the rate of this reaction.

However, the effect was not the same in the production of individual CLA as for trans-C18:1 isomers: trans-10 isomers were increased and trans-11 isomers were decreased by $150^{\circ} \mathrm{C}$ heating. In fact, the diminution of total CLA production was caused mainly by the inhibition of the production of the main CLA isomer, cis-9,trans-11-CLA, and to a lesser degree to the inhibition of the production of cis-9,cis-11-CLA by long heating duration and of trans-9,trans-11-CLA by high heating temperature. Hence, there was an inhibition of the $\Delta^{12}$-isomerization. In contrast, there was an increase in produced quantities of trans-10, cis-12-CLA with heating temperature and duration, suggesting an enhancement of the $\Delta^{9}$ isomerase activity.

Similarly, the amount of trans-11-C18:1 produced was significantly reduced for the 6 -h duration and $150^{\circ} \mathrm{C}$ temperature, which suggested an inhibition of the $\Delta^{12}$-isomerization; the trans-10-C18:1 increase for $150^{\circ} \mathrm{C}$ heating could be linked to a more important $\Delta^{9}$-isomerization. The inhibitory effect of heating duration and temperature on trans-11 isomers in ruminal cultures has been previously reported in a preliminary study in vitro (Troegeler-Meynadier et al., 2006c), and cis-9,trans-11-CLA and trans-11-C18:1 percentages in milk were reported to decrease when dairy cows ingested oxidized soybean oil with PV $=240 \mathrm{mEq} / \mathrm{kg}$ of oil (Vazquez-Anon et al., 2008). Conversely, studies with heated oilseeds (Chouinard et al., 1997a; TroegelerMeynadier et al., 2006b; Neves et al., 2007) reported an accumulation of cis-9,trans-11-CLA isomers, trans11-C18:1 isomers, or both. The nature, or the amount, or both, of oxidized products generated during heating may depend on the form of fat (oil vs. seed) and on the heating process (extrusion, roasting, and so on), which could explain the differences among these studies.

Effect of heating on trans-10 isomer production has not yet been reported. Nevertheless, the increase of trans-10,cis-12-CLA in cultures with heated oil observed in this study could explain the decrease of milk fat content noticed in some in vivo studies with the use of extruded soybeans compared with raw soybeans (Guillaume et al., 1991; Neves et al., 2007) because this isomer causes a decrease in milk fat content (Baumgard et al., 2000).

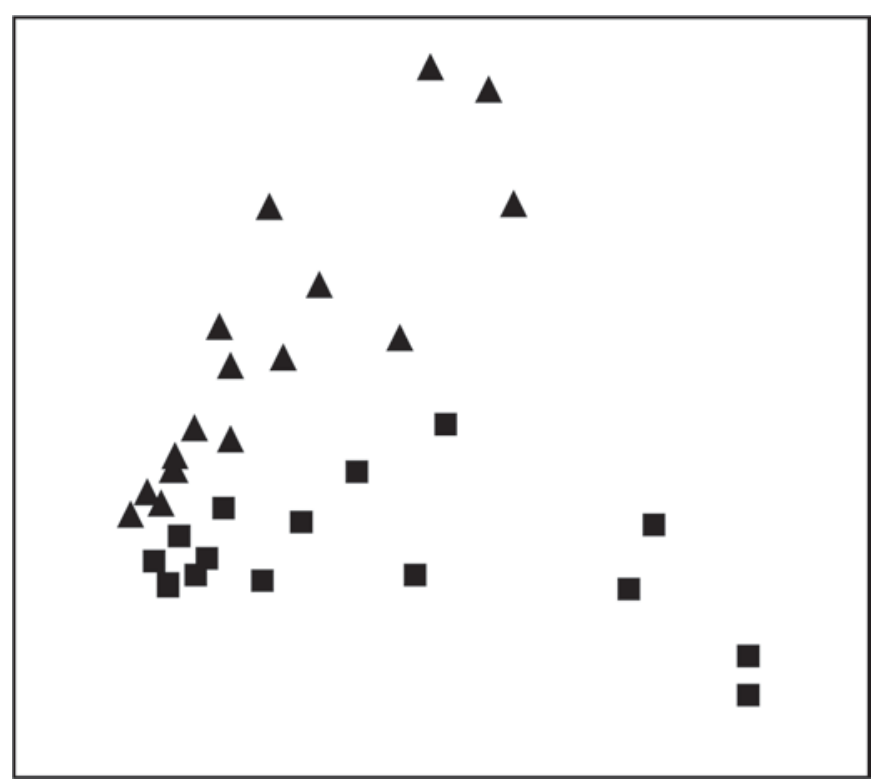

Figure 1. Two-dimensional nonmetric multidimensional scaling plot of the 33 capillary electrophoresis single-strand conformation polymorphism profiles from the ruminal cultures incubated for $6 \mathrm{~h}$ with oil heated at $110^{\circ} \mathrm{C}(\boldsymbol{\Delta})$ or $150^{\circ} \mathrm{C}(\boldsymbol{\square})$ regardless of the duration of heating. Analysis of similarity $\mathrm{R}$-value $=0.21 ; P<0.01$. 
Heated Oils Could Act Directly on Biohydrogenation Reactions and on Ruminal Bacteria

The action of heating duration and temperature of oil occurred principally on the isomerization process, but an additional action on lipolysis could not be excluded. The heated oils could act either on the reaction or on isomerizating bacteria. The isomerizations of cis9, cis-12-C18:2 to trans-10,cis-12-CLA and cis-9,trans11-CLA do not follow the same pathways (Wallace et al., 2007) and are not performed by all bacteria; fibrolytic bacteria, belonging to the Butyrivibrio genus, produce only trans-11 isomers (Maia et al., 2007; Wallace et al., 2007), and some lactate-consuming bacteria predominantly produce trans-10 isomers (Verhulst et al., 1987; Kim et al., 2002; Wallace et al., 2007). As a consequence, the effects of heated oils on each pathway could be different: activation of $\Delta^{9}$-isomerization versus inhibition of $\Delta^{12}$-isomerization.

The $\Delta^{12}$-isomerization is a radical reaction, possibly initiated by hydrogen abstraction on C-11 catalyzed by a radical intermediate enzyme (Wallace et al., 2007). The cis-9,cis-12-C18:2 oxidation is also a radical reaction that also begins by an hydrogen abstraction on C-11 (Spiteller et al., 2001), so that some common intermediates or some structural analogs generated during oxidation could interfere with the $\Delta^{12}$-isomerization. This explanation cannot apply to the activation of $\Delta^{9}$-isomerization, which is not a radical intermediate reaction but rather an ionic reaction with a carbocation as an intermediate (Liavonchanka et al., 2006; Wallace et al., 2007).

These 2 pathways of cis-9,cis-12-C18:2 BH are realized by different bacteria: trans-11 isomers are produced mostly by fibrolytic bacteria (mainly Butyrivibrio fibrisolvens and to a lesser extent Butyrivibrio proteoclasticus, formerly Clostridium proteoclasticum; Moon et al., 2008), whereas the trans-10 isomers are produced by lactate-consuming bacteria (Propionibacterium acnes, or Megasphaera elsdenii, or both; Kim et al., 2002; Maia et al., 2007; Wallace et al., 2007). Heated oils could contain products that inhibit the growth or activity of fibrolytic bacteria and favor those of $P$. acnes and M. elsdenii. This hypothesis is strengthened by other modifications in the production of fatty acids. In our experiment, heating increased the production of trans10,trans12-CLA and trans12-C18:1, and $P$. acnes is known to produce trans-10,trans-12-CLA (Wallace et al., 2007), which is partly reduced to trans12-C18:1 (Shingfield et al., 2008). Similar results were obtained by Choi et al. (2005) studying the effect of oxygen on CLA production by mixed ruminal bacteria. They showed that in aerobic conditions, more trans10,cis-12-CLA accumulated than cis-9,trans-11-CLA and concluded that bacteria producing trans-10, cis-12CLA were more aero tolerant than bacteria producing cis-9,trans-11-CLA. This tolerance could be because of the production of antioxidant enzymes like superoxide dismutase and glutathione peroxidase by ruminal bacteria, as shown on Streptococcus bovis and Selemonas ruminantium (Lenartova et al. 1998). On the other hand, Hino et al. (1993) demonstrated that vitamin E and $\beta$-carotene increased growth of fibrolytic bacteria, possibly by decreasing the noxious effect of oxidative compounds. As a consequence, oxidative compounds would be more noxious for fibrolytic bacteria than for lactate consumers and therefore increase the participation of bacteria producing trans-10, cis-12-CLA relative to that of bacteria producing cis-9,trans-11-CLA.

In the present work, we studied the whole bacterial community dynamics using CE-SSCP (Hori et al., 2006; Michelland et al., 2009b). Temperature of oil heating modulated the structure of the ruminal bacterial population. Heating at $150^{\circ} \mathrm{C}$ could generate 1 or several oxidative products that could alter the microbial population. This hypothesis was supported by cis-9,cis-12-C18:2 $\mathrm{BH}$ and its intermediates being very closely linked to the bacterial community D' (Table 5). Estimating D' consists of summarizing a complex community represented by a molecular fingerprint pattern in a single value by taking into account the number of species (number of peaks) and their relative abundance (area under each peak; Michelland et al., 2009b). The lowest value of $\mathrm{D}^{\prime}$ is obtained when the profile contains only 1 peak and the highest value of $\mathrm{D}^{\prime}$ obtained when the profile contains many overlapping peaks of equal abundance. Thus, the positive relationship between C18:2 BH process and $\mathrm{D}^{\prime}$ indicated (Table 5) that the lowering effect of heated oils on the diversity of the bacterial community makes the $\mathrm{BH}$ process less efficient.

The heating of oils generates many different oxidative products that could act on the reaction of $\mathrm{BH}$ or directly on the bacteria. The parallel evolution between PV and cis-9,cis-12-C18:2, CLA, and trans-C18:1 intermediates of cis-9,cis-12-C18:2 BH, underlined by significant linear relationships and a major effect of the 150-6 oil treatment (highest PV), confirmed their possible effect on $\mathrm{BH}$. Therefore, fatty acid peroxidation might explain, at least in part, our results. In this first approach, PV was chosen to estimate the oxidative status of the oils; however, it cannot allow a precise estimation of the different products generated by oxidation. Because heating duration did not modify bacterial population while affecting $\mathrm{BH}$, and heating temperature modified bacterial population, we hypothesized that at least 2 or more oxidative compounds were involved: first(s) accumulated for long-duration heating, acting directly on the $\Delta^{12}$ isomerase, and other(s), identical or not, 
produced at high temperature and able to act on the microorganisms. This is supported by the strong negative linear relationship that existed between trans-11 isomers and PV because this isomerization may be affected by these 2 actions; bacteria producing trans-11 were probably more affected by peroxides and so produced fewer trans-11 isomers, and $\Delta^{12}$ isomerase was inhibited by these compounds (Table 6). Conversely, trans-10 isomers were positively, and to a lesser, extent linked to the PV, showing that the appearance of these isomers would not be directly linked to the presence of peroxides but rather probably was a result of the higher resistance of the bacteria producing trans-10 to these compounds. The nature of these oxidative products was not determined here, and few data exist in the literature about the effect of the different oxidative products on BH. Contrary to our results, Lee et al. (2007) observed a stimulation of $\mathrm{BH}$ and therefore an increase of the production of CLA and trans-11-C18:1, and a decrease of trans-10,cis-12-CLA and trans-10-C18:1, when using pure trans-2-decenal, which is an end product of cis9,cis-12-C18:2 oxidation (Spiteller et al., 2001). In the present study, oil was rapidly frozen at $-80^{\circ} \mathrm{C}$ so that radical intermediates and hydroperoxides, which are formed at the beginning of oxidation, were probably the dominant oxidative products. Terminal oxidation products need more time to accumulate. They probably act differently on $\mathrm{BH}$ compared with peroxides. This underlines the importance of distinguishing oxidative products and their different capacity to modulate $\mathrm{BH}$.

\section{CONCLUSIONS}

Increasing the duration and temperature of heating of sunflower oil had a synergistic action on cis-9, cis12-C18:2 BH. An overall decrease in cis-9, cis-12-C18:2 disappearance occurred, leading to an overall decrease in CLA and trans-C18:1 production because of a decreased production of cis-9,trans-11-CLA and trans11-C18:1. In contrast, there was an increase in the production of trans-10 isomers, mainly because of high heating temperature. Our results suggest that heating at high temperature would act via a modulation of the bacterial community, whereas increasing heating duration would not. Oxidative compounds produced during oil heating could explain, at least in part, these effects. They could act on BH reactions by generating substances directly affecting isomerases, or by stimulating or inhibiting specific bacterial communities, or both. Oxidative compound(s) accumulated during heating would act directly on the isomerization step, and oxidative compound(s), identical or not, generated only at high temperature would be able to affect bacterial population equilibrium. In this study, PV was used as a proxy for cis-9,cis-12-C18:2 oxidation but did not reflect the production of other oxidative products (i.e., triglycerides oxipolymers, ketones, aldehydes). Further studies are therefore necessary to identify precisely which oxidative products affect $\mathrm{BH}$.

\section{ACKNOWLEDGMENTS}

The authors thank B. Gabinaud, M. L. Chemit, and the staff at the experimental station (UMR 1289 Tandem, Castanet-Tolosan, France).

\section{REFERENCES}

AFNOR. 2004. Détermination de l'indice peroxyde. Corps gras d'origines animale et végétale. In Collection de Normes Françaises et de Méthodes Communautaires. Aliments des Animaux. Méthodes d'Analyse. AFNOR ISO 3960. Association Française de Normalisation, Paris, France.

Akraim, F., M. C. Nicot, P. Weil, and F. Enjalbert. 2006. Effects of preconditioning and extrusion of linseed on the ruminal biohydrogenation of fatty acids. 1. In vivo studies. Anim. Res. 55:83-91.

Baumgard, L. H., B. A. Corl, D. A. Dwyer, A. Saebo, and D. E. Bauman. 2000. Identification of the conjugated linoleic acid isomer that inhibits milk fat synthesis. Am. J. Physiol. Regul. Integr. Comp. Physiol. 278:R179-R184.

Brioukhanov, A. L., and A. I. Netrusov. 2004. Catalase and superoxide dismutase: Distribution, properties, and physiological role in cells of strict anaerobes. Biochemistry (Mosc.) 69:949-962.

Choi, N. J., J. Y. Imm, S. Oh, B. C. Ki, H. J. Hwang, and Y. J. Kim. 2005. Effect of $\mathrm{pH}$ and oxygen on conjugated linoleic acid (CLA) production by mixed rumen bacteria from cows fed high concentrate and high forage diets. Anim. Feed Sci. Technol. 123124:643-653.

Chouinard, P. Y., V. Girard, and G. J. Brisson. 1997a. Performance and profiles of milk fatty acids of cows fed full fat, heat-treated soybeans using various processing methods. J. Dairy Sci. 80:334342 .

Chouinard, P. Y., J. Levesque, V. Girard, and G. J. Brisson. 1997b. Dietary soybeans extruded at different temperatures: Milk composition and in situ fatty acid reactions. J. Dairy Sci. 80:2913-2924.

Delbès, C., J. J. Godon, and R. Moletta. 1998. 16S rDNA sequence diversity of a culture-accessible part of an anaerobic digestor bacterial community. Anaerobe 4:267-275.

Enjalbert, F., and A. Troegeler-Meynadier. 2009. Biosynthesis of trans fatty acids in ruminants. Pages 1-42 in Trans Fatty Acids in Human Nutrition. 2nd ed. F. Destaillats, J. L. Sébédio, F. Dionisi, and J. M. Chardigny, ed. The Oily Press, P. J. Barnes \& Associates, Bridgwater, UK.

Gonthier, C., A. F. Mustafa, D. R. Ouellet, P. Y. Chouinard, R. Berthiaume, and H. V. Petit. 2005. Feeding micronized and extruded flaxseed to dairy cows: Effects on blood parameters and milk fatty acid composition. J. Dairy Sci. 88:748-756.

Griinari, J. M., and D. E. Bauman. 1999. Biosynthesis of conjugated linoleic acid and its incorporation into meat and milk in ruminants. Pages 180-200 in Advances in Conjugated Linoleic Acid Research. M. P. Yurawecz, M. M. Mossoba, J. K. G. Kramer, M. W. Pariza, and G. J. Nelson, ed. AOCS Press, Champaign, IL.

Griinari, J. M., B. A. Corl, S. H. Lacy, P. Y. Chouinard, K. V. Nurmela, and D. E. Bauman. 2000. Conjugated linoleic acid is synthesized endogenously in lactating dairy cows by delta(9)-desaturase. J. Nutr. 130:2285-2291.

Guillaume, B., D. E. Otterby, M. D. Stern, J. O. Linn, and D. O. Johnson. 1991. Raw or extruded soybeans and rumen-protected methionine and lysine in alfalfa-based diets for dairy cows. J. Dairy Sci. 74:1912-1922. 
Hino, T., N. Andoh, and H. Ohgi. 1993. Effects of $\beta$-carotene and $\alpha$-tocopheol on rumen bacteria in the utilization of long-chain fatty acids and cellulose. J. Dairy Sci. 76:600-605.

Hori, T., S. Haruta, Y. Ueno, I. Masaharu, and Y. Igarashi. 2006. Direct comparison of single-strand conformation polymorphism (SSCP) and denaturing gradient gel electrophoresis (DDGE) to characterize a microbial community on the basis of $16 \mathrm{~S}$ rRNA gene fragments. J. Microbiol. Methods 66:168-169.

Kim, Y. J., R. H. Liu, J. L. Rychlik, and J. B. Russell. 2002. The enrichment of a ruminal bacterium (Megasphaera elsdenii YJ-4) that produces the trans-10, cis-12 isomer of conjugated linoleic acid. J. Appl. Microbiol. 92:976-982.

Lee, M. R., S. A. Huws, N. D. Scollan, and R. J. Dewhurst. 2007. Effects of fatty acid oxidation products (green odor) on rumen bacterial populations and lipid metabolism in vitro. J. Dairy Sci. 90:3874-3882

Lenartova, V., K. Holovska, and P. Javorsky. 1998. The influence of mercury on the antioxidant enzyme activity of rumen bacteria Streptococcus bovis and Selenomonas ruminantium. FEMS Microbiol. Ecol. 27:319-325.

Liavonchanka, A., E. Hornung, I. Feussner, and M. G. Rudolph. 2006. Structure and mechanism of the Propionibacterium acnes polyunsaturated fatty acid isomerase. Proc. Natl. Acad. Sci. USA 103:2576-2581.

Maia, M. R. G., L. C. Chaudhary, L. Figueres, and R. J. Wallace. 2007. Metabolism of polyunsaturated fatty acids and their toxicity to the microflora of the rumen. Antonie Van Leeuwenhoek 91:303-314.

Michelland, R., S. Déjean, S. Combes, L. Fortun-Lamothe, and L. Cauquil. 2009a. StatFingerprints: A friendly graphical interface program for processing and analysis of microbial fingerprints profiles. Mol. Ecol. Resour. 9:1359-1363.

Michelland, R. J., V. Monteils, A. Zened, S. Combes, L. Cauquil, T. Gidenne, J. Hamelin, and L. Fortun-Lamothe. 2009b. Spatial and temporal variations of the bacterial community in the bovine digestive tract. J. Appl. Microbiol. 107:1642-1650.

Moon, C. D., D. M. Pacheco, W. J. Kelly, S. C. Leahy, D. Li, J. Kopecny, and G. T. Attwood. 2008. Reclassification of Clostridium proteoclasticum as Butyrivibrio proteoclasticus comb. nov., a butyrate-producing ruminal bacterium. Int. J. Syst. Evol. Microbiol. 58:2041-2045.

Neves, C. A., G. T. Santos, M. Matsushita, E. M. Alves, R. L. Oliveira, A. F. Branco, D. C. Silva, A. C. Furlan, and H. V. Petit. 2007. Intake, whole tract digestibility, milk production and milk composition of Holstein cows fed extruded soybeans treated with or without lignosulfonate. Anim. Feed Sci. Technol. 134:32-44.

Pariza, M. W., Y. Park, and M. E. Cook. 2001. The biologically active isomers of conjugated linoleic acid. Prog. Lipid Res. 40:283-298.

Park, P. W., and R. E. Goins. 1994. In situ preparation of fatty acid methyl esters for analysis of fatty acid composition in foods. J. Food Sci. 59:1262-1266.
Reddy, P. V., J. L. Morrill, and T. G. Nagaraja. 1994. Release of free fatty acids from raw or processed soybeans and subsequent effects on fiber digestibilities. J. Dairy Sci. 77:3410-3416.

Riserus, U., P. Arner, K. Brismar, and B. Vessby. 2002. Treatment with dietary trans10cis12 conjugated linoleic acid causes isomer-specific insulin resistance in obese men with the metabolic syndrome. Diabetes Care 25:1516-1521.

Rosenzweig, M. L. 1995. Species Diversity in Space and Time. Cambridge University Press, Cambridge, UK.

Shingfield, K. J., S. Ahvenjärvi, V. Toivonen, A. Vanhatalo, P. Huhtanen, and J. M. Griinari. 2008. Effect of incremental levels of sunflower-seed oil in the diet on ruminal lipid metabolism in lactating cows. Br. J. Nutr. 99:971-983.

Spiteller, P., W. Kern, J. Reiner, and G. Spiteller. 2001. Aldehydic lipid peroxidation products derived from linoleic acid. Biochim. Biophys. Acta 1531:188-208.

Troegeler-Meynadier, A., L. Bret-Bennis, and F. Enjalbert. 2006a. Rates and efficiencies of reactions of ruminal biohydrogenation of linoleic acid according to $\mathrm{pH}$ and polyunsaturated fatty acids concentrations. Reprod. Nutr. Dev. 46:713-724.

Troegeler-Meynadier, A., M. C. Nicot, and F. Enjalbert. 2006b. Effects of heating process of soybeans on ruminal production of conjugated linoleic acids and trans-octadecenoic acids in situ. Rev. Med. Vet. (Toulouse) 157:509-514.

Troegeler-Meynadier, A., Y. Zhao, and F. Enjalbert. 2006c. Effects of duration and temperature of heating of sunflower oil on ruminal linoleic acid biohydrogenation in vitro. 4th Euro Fed Lipid Congress-Fats, Oils, and Lipids for a Healthier Future, Workshop: Rumen Biohydrogenation, Madrid, Spain.

Vazquez-Anon, M., J. Nocek, G. Bowman, T. Hampton, C. Atwell, P. Vazquez, and T. Jenkins. 2008. Effects of feeding a dietary antioxidant in diets with oxidized fat on lactation performance and antioxidant status of the cow. J. Dairy Sci. 91:3165-3172.

Verhulst, A., G. Janssen, G. Parmentier, and H. Eyssen. 1987. Isomerization of polyunsaturated fatty acids by propionibacteria. Syst. Appl. Microbiol. 9:12-15.

Wallace, R. J., N. McKain, K. J. Shingfield, and E. Devillard. 2007. Isomers of conjugated linoleic acids are synthesized via different mechanisms in ruminal digesta and bacteria. J. Lipid Res. 48:2247-2254.

Zumstein, E., R. Moletta, and J. J. Godon. 2000. Examination of two years of community dynamics in an anaerobic bioreactor using fluorescence polymerase chain reaction (PCR) single-strand conformation polymorphism analysis. Environ. Microbiol. 2:6978. 